\title{
紫外線吸収を利用した気体の可視法
}

\author{
森永智昭*・山本圭治郎**・倉石達夫***
}

* 東京工業大学工学部 東京都目黑区大岡山 2-12-1

***大阪大学工学部 大阪市都島区東野田町 9

*** 日本鋼管(株)福山製鉄所 福山市鋼管町 1

(昭和 46 年 1 月 5 日 受付)

\section{Visualization of Gas Flow by Ultraviolet-Absorption}

\author{
Tomoaki Morinaga*, Keijiro Yamamoto**, Tatsuo Kuraishi***

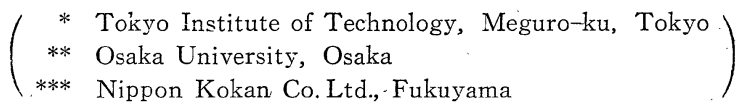

(Received January 5, 1971)

\begin{abstract}
Visualization of gas flow is a very important technique for the study of fluidic elements, but it is far more difficult than the visualization of liquid flow. Except some impractical optical methods, most methods for gas flow visualization utilize some tracer in the flow, and in most cases the tracer undesirably changes the flow characteristics. It is desirable, therefore, that the tracer and the operating gas possess the closest resemblance in their flow characteristics.

Ozone absorbs very strongly the ultraviolet radiation of 200 to 300 millimicron wavelength. Therefore, by illuminating a fluorescent plate with parallel ultraviolet radiation through the gas flow, the flow containing ozone can be visualized as a dark silhouette on the plate. The visualization technique based upon this principle was applied to the wall attachment fluidic elements, and it was revealed that the amount of ozone necessary to visualize the air flow is so small that it can hardly affect the flow characteristics. It is also possible to observe the transient state of the flow. by adding ozone intermittently into the flow.
\end{abstract}

\section{1. は じめに}

気体流れ，特に純流体素子内の空気の流机の可視化

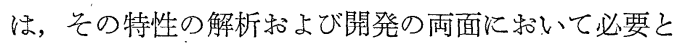
される. 従来可能であったのは主として定常流れの可 視化で㐫り，乙か子定性的なるのが多かったが，之う ぜんこれだけでは十分とはい党ず，非定常流れの可視 化とその定量的測定が必須である. 特に非定常流れの 可視法に和いては，流れの中に混合するトレーサとし ては，その流れに影響する特性が使用流体になるべく 近いものが望むしく，乙か子その発生を制御すること が望をしい，純流体素子の場合は，特に流れの局部々 ともに全体を観測する必要がある。

これらの要求を満たす可視法として, オゾンが紫外 † 第 5 回純流体素子シンポジムで発表 (昭 45・9)
線を強く吸收する性質を利用する方法が考光られる。 すなわちトレーサとしてオン゙ンを用いるるので，この オゾンは放電によって空気中に空間的にも時間的にも 一様に発生させることができる，このオゾンを含んだ 空気流を観測する流路に供給し，この流路を平行紫外 線で照射して，透過光をけい光板で可視光線に変換す れば，空気の流れが影となって見える（Fig. 1).

この原理による装置を試作し, 純流体素子の流れの 観測に適用して，良好な結果を得た。

\section{2. 一原理}

\section{$2 \cdot 1$ オゾンの紫外線吸収特性}

オン゙ンは波長 2000 3 $000 \AA$ 飞吸收帯を持ち，そ の極大点は $2537 \AA$ 付近にある. Lambert-Beer の 法則によれば，強さ $I_{i}$ の入射光が，濃度 $C \mathrm{mg} / l$ で 


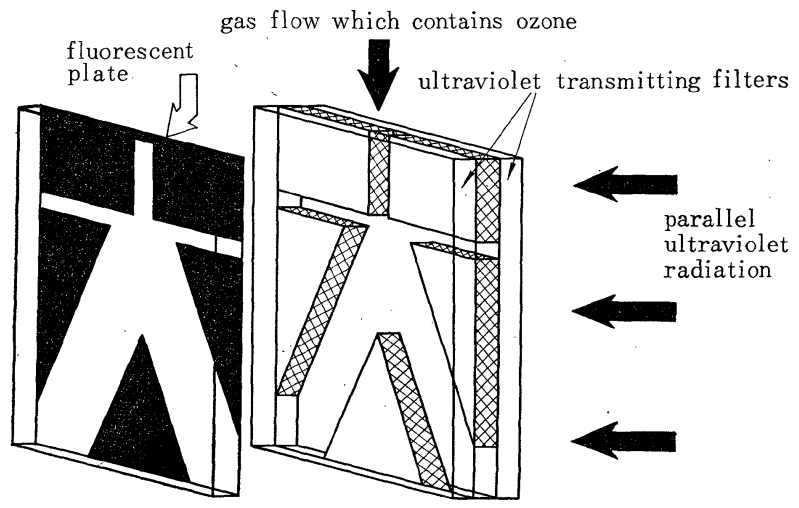

Fig. 1 Principle of visualization of gas flow by ultraviolet-absorption

厚さ $b \mathrm{~cm}$ の吸収物質層を透過した場合, その透過光 の強さを $I_{t} ; a$ を吸収係数 $[l / \mathrm{mg} \cdot \mathrm{cm}]$ とすると, 次 の関係がある。

$$
\log _{10} \frac{I_{i}}{I_{t}}=a b c
$$

ここで，aの值は入射光の波長と吸光物質によって 決まる定数であり，入射光が $2537 \AA$ ，物質がオゾン

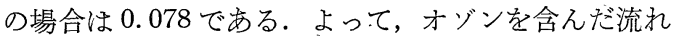
の厚さ $b$ が一定であれば，オゾンによる $2537 \AA$ 付 近の光束吸収率の対数とオゾンの濃度とが比例する.

\section{$2 \cdot 2$ けい光物質}

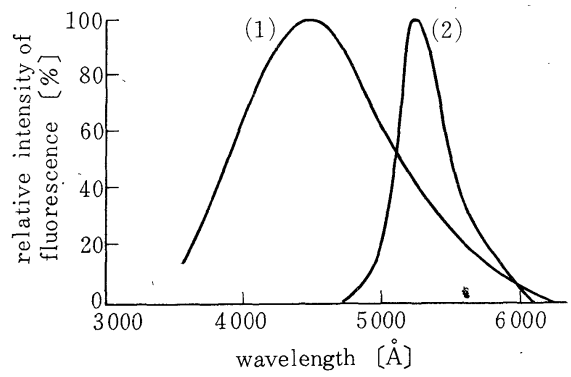

(1) $\mathrm{CaWO}_{4}-\mathrm{W}$ (2) $\mathrm{ZnSiO}_{4}-\mathrm{Mn}$

(a) emission bands

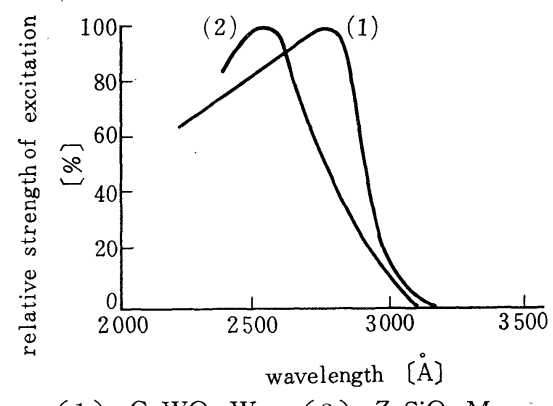

(1) $\mathrm{CaWO}_{4}-\mathrm{W} \quad$ (2) $7 \mathrm{nSiO}_{4}-\mathrm{Mn}$

(b) excitation bands

Fig. 2 Characteristics of flnorəscent materials
けい光物質は, 外部からの光エネルギの刺激 によってそのエネルギを吸收し，このエネルギ を受けている間だけェネルギの放射（けい光） を行なら物質であるが，Stokes の法則により， けい光の波長は吸収光の波長よりも長い. Fig. 2 に, $2537 \AA$ 付近に励起帯を持ち残光性のき わめて短い各種けい光物質の励起带とけい光带 を示す。

けい光物質が照射光から吸収した光量とけい 光強度とが比例することから，げい光板のけい 光強度は, 照射光強度に比例する。

\section{$2 \cdot 3$ オゾンの特性}

気態オゾンの密度は現在まで直接実験的には 求められて抢らず，完全気体として， $20{ }^{\circ} \mathrm{C}$ に 执いて $2.144 \mathrm{~g} / l$ とされている. 安定性に関しては; ある濃度のオゾンガスを完全密閉した箱内に自然放置 した場合，濃度は時間飞関して指数的に減じ，約 1 時 間で濃度が $1 / 2$ になることが知られている。オン゙ンの 分解速度は温度に正比例し, また, 水蒸気の存在によ って大きくなる。

\section{4 オゾンの生成方法}

能率が良く生成量の多いるのとしては，現在無声放 電法が唯一のものである．無声放電はガラスのような 絶縁物を通した空げき内の放電をいい，ガラスが安定 層となり，放電が局部に集中するのをさまたげ，発達 した放電形成に移行することを抑制する。したがって この放電形成は過渡的な段階であって，そのさいの衝 琵突電離は，通常の方法では困難な化学反応を能率良く 起こさせることができる，オゾンは，空気または酸素 を原料として無声放電場を通過させることにより得ら れる、この方法によってオゾンを生成する装置をオゾ ナイザと呼んでいる.

\section{$2 \cdot 5$ オゾナイザの設計法}

オゾナイザ内に括けるオゾン生成条件がをだ完全に わかっていないため，実験データを基にして電気工学 的設計法によっているのが現状である.

設計に打いて一番問題となる点はオゾナイザの収率 $\left[\mathrm{O}_{3} \mathrm{~g} / \mathrm{kWh}\right]$ であるが，これについての十分なデータ がそろっていない（特に円筒形のもの以外は見当たら ない)。ここではオン゙ナイザとして，並ガラスを用い た二重円筒管で内径 $30 \mathrm{~mm}$, 外径 $45 \mathrm{~mm}$, 長さ 380 $\mathrm{mm}$, 空げき長さ $5 \mathrm{~mm}$, ガラス厚 $1.25 \mathrm{~mm}$, 空げき 容積 $220 \mathrm{~cm}^{3}$ のものを用いた, E. Briner ${ }^{1), 2)}$ の発表 した值（Fig. 3) から収率を求める。乙たがって以下 に述べるのは円筒形オゾナイザの設計法である.

まず，原料ガスと電源周波数 $f \mathrm{~Hz}$ を選び，必要之 


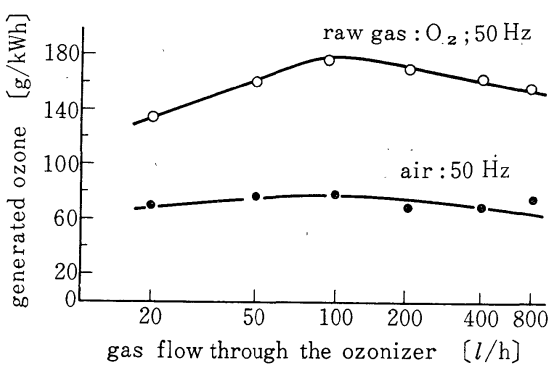

Fig. 3 Characteristics of the ozonizer (experimental results of E. Briner)

する流量から Fig. 3 により収率を求める．次に必要 なオゾン濃度 $[\mathrm{g} / \mathrm{l}]$ と流量からオゾン生成量 $[\mathrm{g} / \mathrm{h}]$ を決め, これと収率からオゾナイザの放電電力 $W \mathrm{~W}$ が求まる，Wが決まれば，オン゙ナイザに用いる誘電 体の最大許容電位傾度 $V_{W S} \mathrm{~V} / \mathrm{cm}$, 誘電率 $\varepsilon_{g}$, 厚さ $d_{g}$ $\mathrm{cm}$ ，原料ガスによって決まるオン゙ナイザの臨界電位 傾度 $v \mathrm{~V} / \mathrm{cm}$ ，ガスの誘電率 $\varepsilon_{a}$, 誘電体の機械的強度 に関する安全率 $s$ を与えて，必要にして最小のオゾ ナイザの空げき長 $d_{a} \mathrm{~cm}$ と有効放電面積 $S \mathrm{~cm}^{2}$ を次 式によって求めることができる.

$$
\begin{aligned}
& d_{a}=\left(\frac{V_{W S}}{s \cdot v}-\frac{\varepsilon_{a}}{2 \varepsilon_{g}}\right) d_{g} \\
& \mathrm{~S}=\frac{W}{f \cdot v^{2} \cdot d_{a}{ }^{2} \cdot \frac{1}{d_{g}} \cdot \frac{\varepsilon_{g}}{4 \pi} \cdot \frac{1}{9} \times 10^{-11}}
\end{aligned}
$$

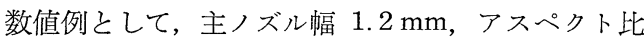
3 の純流体素子の主噴流の可視化に必要なオゾナイザ を設計してみる，2.2 で述べたよらに，けい光強度と 照射光強度が比例するから，けい光板上でノズル出口 付近の主噴流の明るさが周囲の明るさの約 $1 / 10$ にな るようにするには，（1）式から，主噴流のオゾシ濃 度として約 $40 \mathrm{mg} / \mathrm{l}$ を必要とする. 素子への供給流 体を空気とし，流量を最大 $14 \mathrm{l} / \mathrm{min}$ として， $f$ を 50 $\mathrm{Hz}$ とすれば，Fig. 3 から収率は約 $70 \mathrm{~g} / \mathrm{kWh}$ となる。 必要なオゾン生成量は $36.6 \mathrm{~g} / \mathrm{hW}$ となり，けっきょ く $520 \mathrm{~W}$ の放電電力を持つオゾナイザが必要となる。 誘電体を厚さ $0.15 \mathrm{~cm}$ の軟質ガラスとすれば， $V_{W S}$ $=150 \times 10^{3}, \varepsilon_{g}=10, \varepsilon_{a}=1, \quad v=60 \times 10^{3}$ そなり,$s=$ 1 とすれば（2）式から空げき長 $0.74 \mathrm{~cm}$, 有效放電 面積 $651 \mathrm{~cm}^{2}$, 放電空間容積 $482 \mathrm{~cm}^{3}$ を得る. 原料に 酸素を用いれば収率が空気の場合の約 2 倍となり，有 効放電面積も約 $1 / 2$ ですむ。

以上述べた設計法では，特に交流電圧を印加した場 合に起こりやすい沿面放電の問題, 絶縁破壞電圧に対 する温度, 電極面積, 機栈的圧力などの影響を考慮し ていないので，実際オン゙ナイザを製作する場合は，特
にこれらの点に留意する必要がある。

\section{3. 実 験}

\section{$3 \cdot 1$ 実験 装 置}

Fig. 4 亿観測装置を示す. 紫外線の光源は $6 \mathrm{~W}$ 形 低圧水銀灯で，スペクトル分布を Fig. 5 に示す．観 測する流路を照射する紫外線をできるだけ平行にする ために光源背面に反射鏡を置き，さらに直径 $7 \mathrm{~cm}$, 長さ $50 \mathrm{~cm}$ の筒（内壁での反射を防ぐためカーボン を塗布）で紫外線を導いている. 流体は，2 枚の紫外 線透過フィルタの間に流す. 用いたフィルタはコーニ ング社製コードナンバ-7910 と 9863 の 2 枚で，それ ぞれの紫外線透過特性を Fig. 6 亿示す.

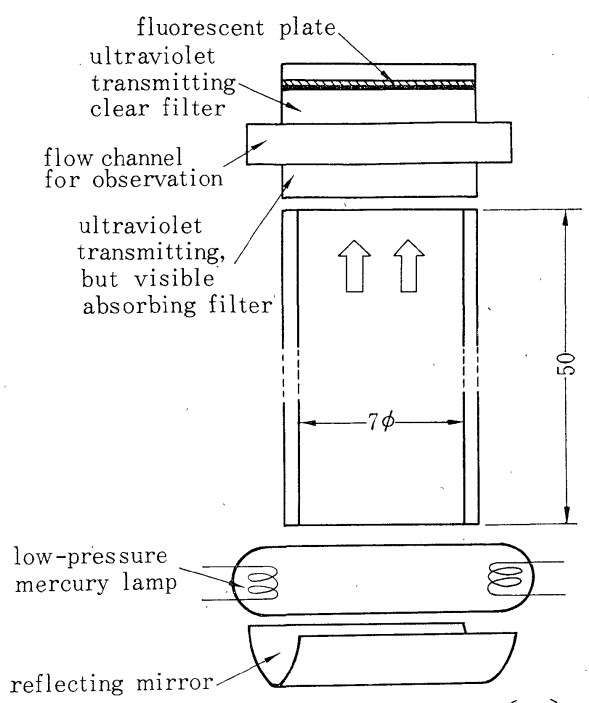

[cm]

Fig. 4 Arrangement of experimental apparatus

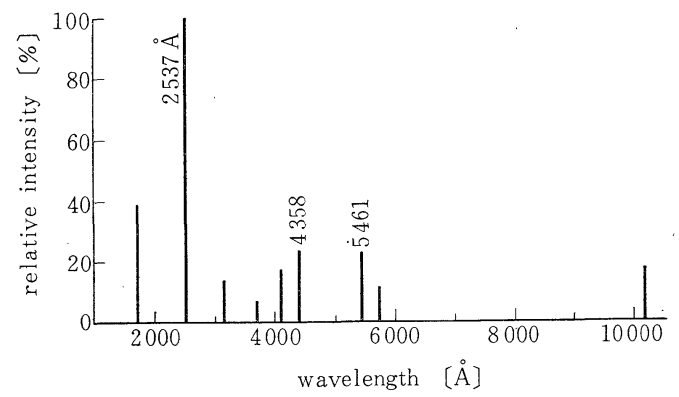

Fig. 5 Spectrum of low-pressure mercury lump emission

けい光板は, 厚さ $1.5 \mathrm{~mm}$ のガラス板にけい酸亜鉛 $\left(\mathrm{ZnSiO}_{4}-\mathrm{Mn}\right)$ を沈殿法によって塗布したるので，塗 布膜厚は発光効率が最大となる $4 \mathrm{mg} / \mathrm{cm}^{2}$ にした.け い光の強さの測定はサンドイッチ形 CdS 光導電素子 


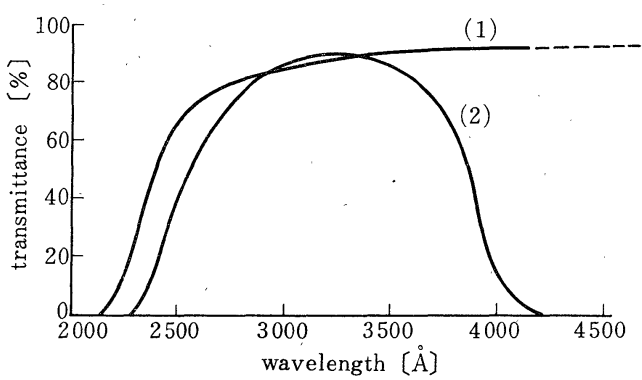

(1) 7910 (number of corning filter glass code) (2) 9863

Fig. 6 Transmission curves of the filters

を用いて行なった．その分光感度特性之照度一明抵抗 特性を Fig.7，Fig.8 にそれぞれ示す．本実験に和け る測定範囲である照度 $0.1 \mathrm{Lx}$ 付近では, 照度と明抵抗

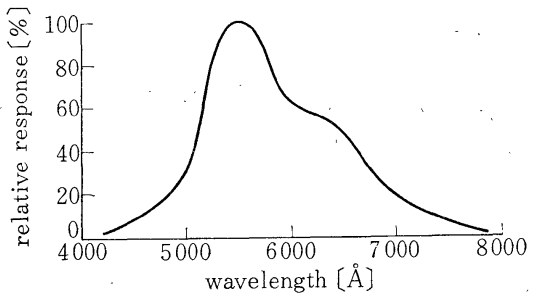

Fig. 7 Spectral response of $\mathrm{CdS}$ photoconductive cell

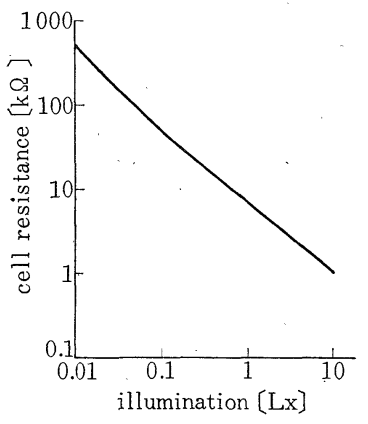

Fig. 8 CdS photoconductive cell resistance vs. illumination
の間に良好な直線性 がある. 受光面值径 は $1 \mathrm{~mm}$ である.け い光板の直径 $1 \mathrm{~mm}$ の部分のけい光のみ を CdS 素子に導く ために内径 $1 \mathrm{~mm}$ 長 さ $6 \mathrm{~mm}$ の内壁が 無反射の筒を受光面 上に垂直に取付けた。

試作したオゾナイ ザの構造を Fig. 9 に

示す．製作の容易さから平板形にした．誘電体には厚 さ $0.2 \mathrm{~cm}$ のソーダガラスを用い，電極にはアルミは くを用いている，空げき長は $0.15 \mathrm{~cm}$ ，有効放電面積 は $190 \mathrm{~cm}^{2}$ のものを 12 層重ねてあり, 計 $2280 \mathrm{~cm}^{2}$, 放電空間容積 $342 \mathrm{~cm}^{2}$ である. 昇圧変圧器は漏えい 変圧器で, $50 \mathrm{~Hz} 100: 9000 \mathrm{~V}, 250 \mathrm{VA}$ のものであ る.

配管はオゾンに直接触れる部分に塩化ビニルパルプ を用いた．原料ガスの脱湿は主として空気の場合問題 になるが，酸素の場合もシリカゲルによって行なった。

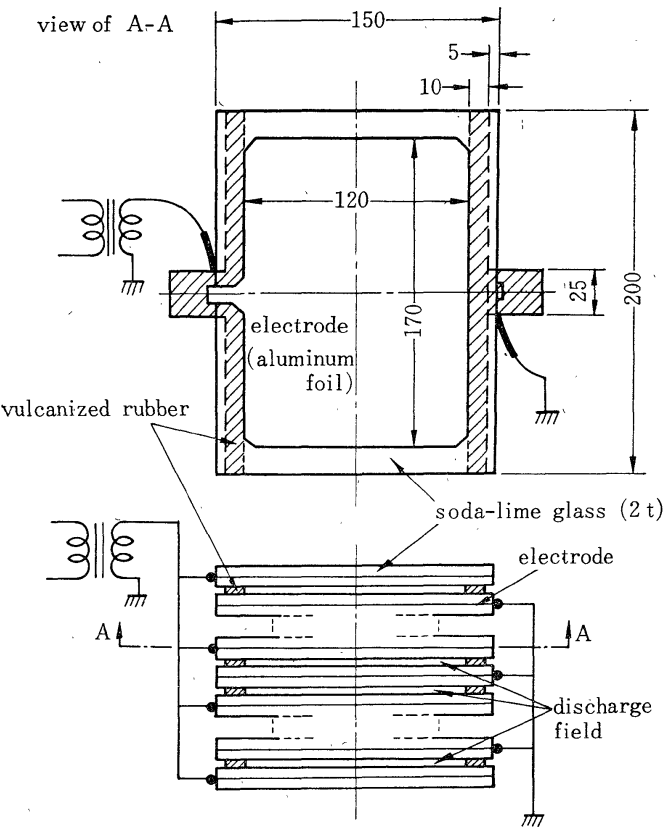

Fig. 9 Structure of the ozonizer

\section{$3 \cdot 2$ 観測装置の特性}

試作した観測装置に打いて, 透過紫外線の強さと CdS 光導電素子によって測定したけい光強さとの間 の比例関係を確かめるために, 光路途中に紫外線透過 フィルタ（透過率約 $80 \%$ のもの）を1〜 7枚そう入 して，紫外線の強さを変えることによって行なった害 験結果を Fig. 10 に示す。良好な直線性がみられた。

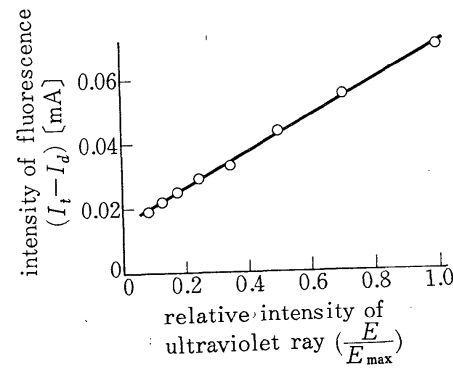

Fig. 10 Intensity of fluorescence vs. intensity of ultraviolet ray

この結果と Lambert-Beer の法則から，オゾン濃度 と, CdS 光導電素子によるけい光強さの測定值をも とにした紫外線束吸収率の対数との間に比例関係があ ると考えられ，これについての実験結果を Fig. 11 に 示守.

\section{$3 \cdot 3$ オゾナイザの特性}

試作したオゾナイザについて，印加電圧と流量とを それぞれ変化させ，オゾナイザを通過させた空気また は酸素を, 幅 $1.2 \mathrm{~mm}$, 深さ $3 \mathrm{~mm}$ の流路に導き, 


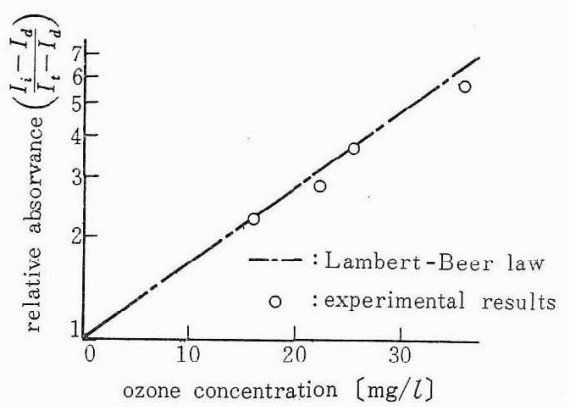

Fig. 11 Ultraviolet absorptive characteristics of ozone

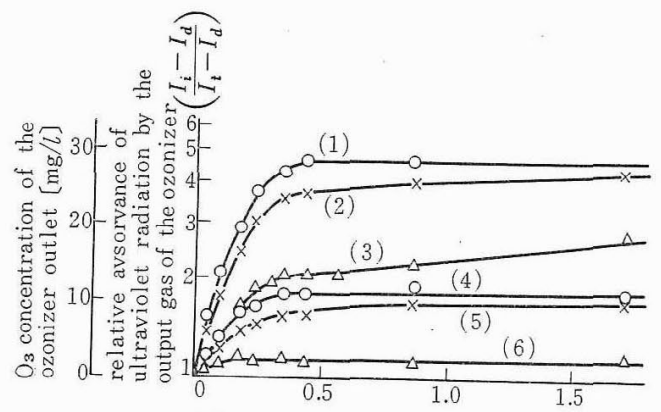

residence time of raw gas in ozonizer [ $\mathrm{min}$ ]

(1) raw gas: $\mathrm{O}_{2} ; 50 \mathrm{~Hz} 5400 \mathrm{~V}$

(2) ": $: \mathrm{O}_{2} ; 50 \mathrm{~Hz} 4000 \mathrm{~V}$

(3) ": $\mathrm{O}_{2} ; 50 \mathrm{~Hz} 3200 \mathrm{~V}$

(4) : $:$ air $; 50 \mathrm{~Hz} 5100 \mathrm{~V}$

(5) ": air; $50 \mathrm{~Hz} 4000 \mathrm{~V}$

(6) ": air; $50 \mathrm{~Hz} 3200 \mathrm{~V}$

Fig. 12 Characteristics of the ozonizer

けい光板のけい光強さを CdS 光導電素子によって測 定した.

Fig. 12 ほ空気または酸素がオゾナイザ内に滞留し た時間と, 紫外線束吸収率 $\left(I_{i}-I_{d} / I_{t}-I_{d}\right)$ の刘数と の関係を示している。 I きの CdS 素子の光電流值， $I_{t}$ はオゾンを含んだ流れ の㐫るときの光電流値で， $I_{d}$ は暗電流である. 109 $\left(I_{i}-I_{a} / I_{t}-I_{d}\right)=a b c=0.078 \times 0.3 \times c$ の関係少占得

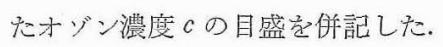

原料ガスが空気の場合之酸素の場合では，オン゙ナイ ザの能率が約 2.5 倍違っている。試作したオゾナイザ の場合，平板形のため沿面放電老起こしやすく，ガラ

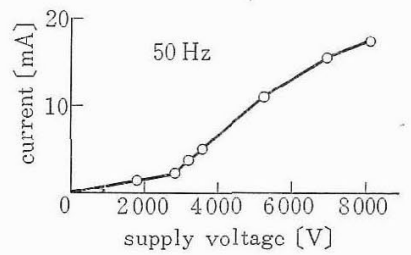

Fig. 13 Current-voltage characteristics of the ozonizer
スの材質の不均一さのため絶縁破壊電圧が低下する 傾向にあったので，印加電圧の最高值は $5400 \mathrm{~V}$ に どめた. Fig. 13 は試作オゾナイザへの印加電圧と電 流との関係を示したものである.

\section{$3 \cdot 4$ 流れの観測}

試作したオゾナイザの能力の制約により，原料ガス として酸素を用いた。なお，酸素の空気に対する比重 は，標準状態で 1.105 でらる。動粘度は空気 13.22 cSt に対して酸素は 13.43 cSt で方る.

写真撮影は，ASA 400 のフィルムを用い, 絞り 3.5 〜 5.6,シャッタスピード 1/15〜1/30 で接写した.

$3 \cdot 4 \cdot 1$ 平行平板の間を流れる噴流の観測観测 に用いたノズルは幅 $1.2 \mathrm{~mm}$ ，アスペクト比 3 であ љ.

Fig. 14-1 2 次元自由貲流で，喏流のレイノルズ 数（ノズル幅を代表長さとした）をそれぞれ 630，740， 1520 付近に变化させたものである.この自由噴流に

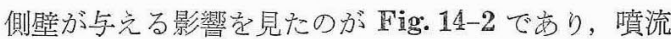
のレイノルズ数は約 750 で古る。（c）は側壁角を大さ

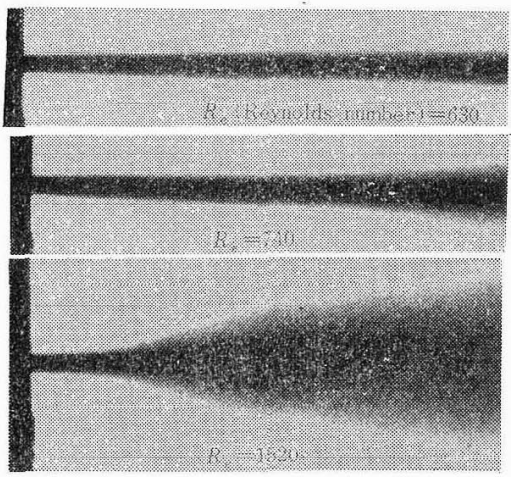

Fig. 14-1 Visualization of two dimensional free jet flow

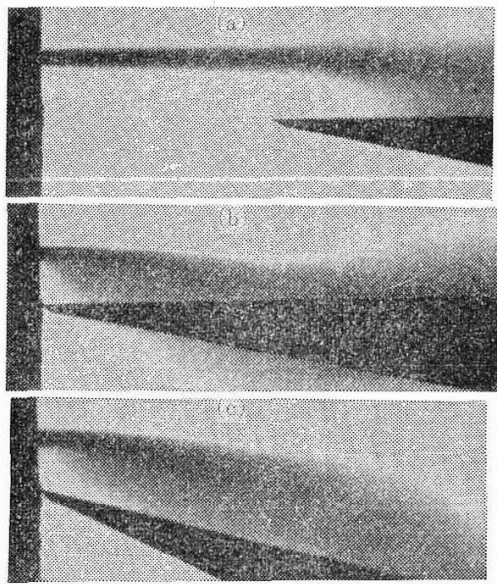

Fig. 14-2 Effect of wall on the jet flow $\left(R_{e}=750\right)$ 
くしていったときの噴流付着限界付近の流れである.

Fig. 14-3 は，スプリッタと側壁の影響を示している. 噴流レイノルズ数は約 740 で，(a)はくさび形のスプ リッタの場合である。（）は）は先端にカスプを持つもの の場合で，側壁がないと噴流は激しく振動し，側壁を 付加すると付着噴波の一部がカスプによってそがれ， それが再び價流にぶつかり，渦を形成して付着を強め る働きをしていることが見られる。
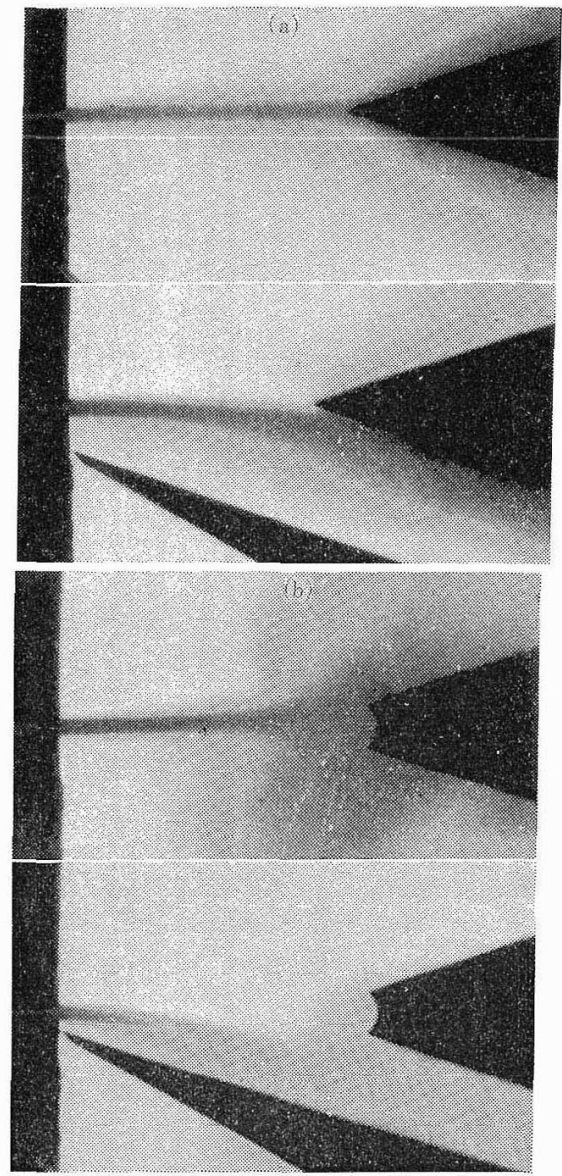

Fig. 14-3 Effect of wall and splitter on the jet flow $\left(R_{\varepsilon}=740\right)$

3.4 .2 側壁付着形素子内の流れの観測 観測に用

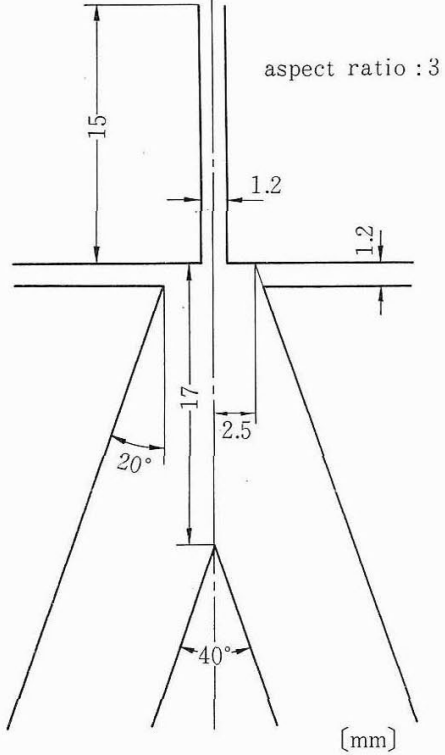

Fig. 15 Pattern of wall-attachment amplifier for the experiments

いたモデル素子の形状，寸法をFig. 15 に示した，供 給ノズル幅は $1.2 \mathrm{~mm}$ でアスペクト比が 3 である.

Fig. 16 は供給圧力をゼロから徐々に上げていき， 主噴流が付着流になるまでの過程を示す（a）は塤流 レイノルズ数が 630 付近の場合で，主塤流はややかた よりを示しているが，まだ付着が安定せず，両出力口 に流出している. (b)は 810 付近のときで,かなり安定 した付着を示しているが，スプリッタ先端と主櫴流の 端が触れて, 渦が生じている.ささらに噴流レイノルズ数 を增して 1040 付近にすると，(c)飞示すよう汇主噴 流は安定した付着流となり，スプリッタ先端の渦は生 じない。

Fig. 17 は制御流をぜロから徐々にふやしていき， 主噴流が切換わるまでの過程を示している。供給圧力 は $17 \mathrm{mmHg}$ で, 主噴流のレイノルズ数は約 6500 で ある。（ａ）は制御口を開放した場合で，（b ）は制御口 圧力 $125 \mathrm{mmAq}$ （c) では $170 \mathrm{mmAq}$ でからうじて 付着を保っている。この制御圧力を越えると切換えが
Fig. 16

Effect of supply pressure on main jet flow in wallattachment amplifier

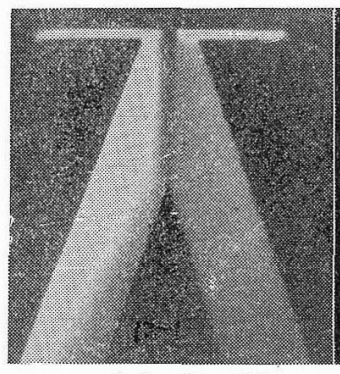

(a) $R_{c}=630$

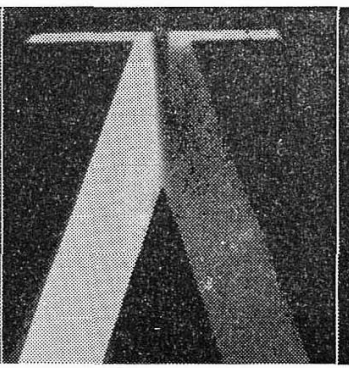

(b) $R_{e}=810$

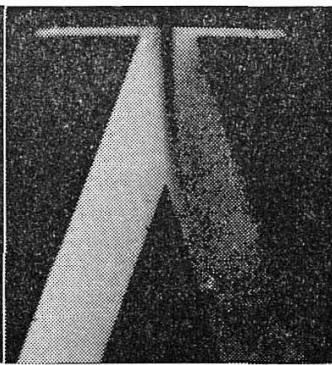

(c) $R_{0}=1040$ 


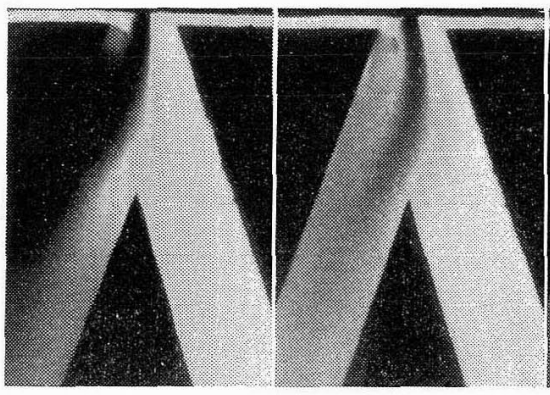

(a)

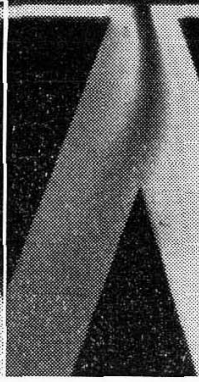

(c)

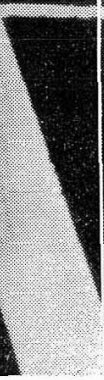

(b)

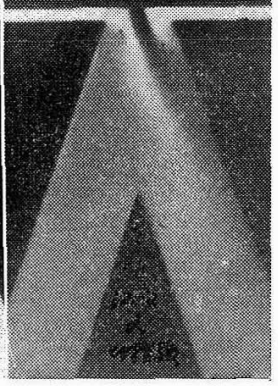

(d)

Fig. 17 Effect of control jet flow on the main jet flow $\left(P_{\mathrm{s}}=17 \mathrm{mmHg}, R_{e}=6500\right)$

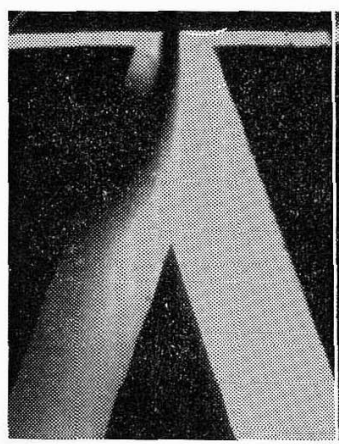

(a)

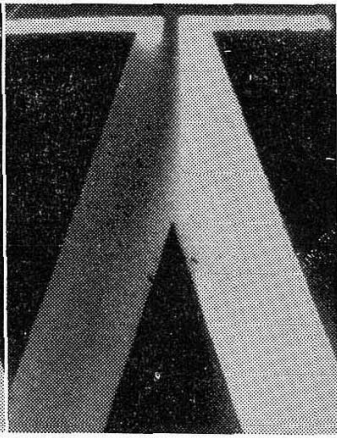

(b)

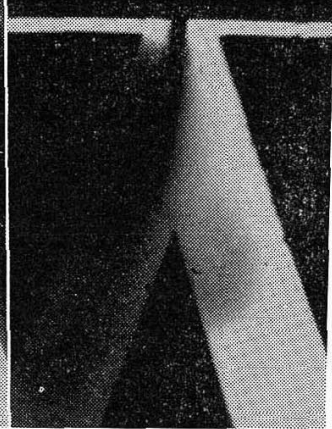

(c) (a) control ports are opened

(b) $P_{0}=125 \mathrm{mmAq}$

(c) $P_{c}=170 \mathrm{mmAq}$, nearly equal to the switching pressure

(d) immediatly after switching

Fig. 18 Effect of load resistance on the main jet flow $\left(P_{s}=12 \mathrm{mmHg}, R_{\mathbf{c}}=3500\right)$

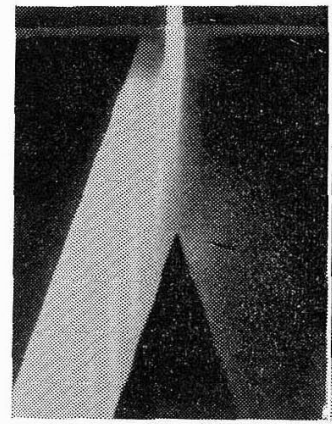

(a) $P_{s}=5 \mathrm{mmHg}$

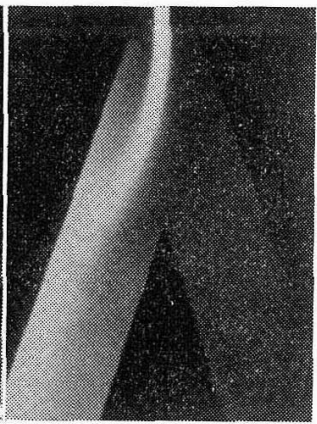

(b) $P_{s}=90 \mathrm{mmHg}$

Fig. 19 Effect of supply pressure on the main jet, when ozone is contained in entrained flow through control nozzless

起きる.（d）注その切換えが起きた直後である. Fig. 18 以負荷をぜ口加ら徐々に增していき，主噴流が切 換わる直前をでの過程を示している．供給圧力は 12 $\mathrm{mmHg}$ で, 主噴流のレイノルズ数は約 3520 で, (a ) は両出力ともに負荷がかかっていない状態である.

（b）では主噴流付着侧出力に比較的小さな負荷がかか っている場合で，すでに主噴流の端がスプリッタ先端 に触れて大きな渦を生じているが，主噴流はまだ非付 着側に流出してはいない（c）はさらに負荷を增して 行き, 主噴流の切換えに必要な最小の負荷がかかって いる状態であり，この直後に主噴流の切換えが起きた。

Fig. 19 では，3台のオゾナイザの入口を開放して， 出口をそれ発れ左右の制御口, 非付着側出力口に接続 し, 吸込名流にオゾンを混入した。供給流を通常の空 気流として，この供給圧力を種々変えたるのである. 各ポートへのオゾナイザの接続が主噴流に与觉る影響 は無視できる程度であった。.

\section{4. お わりに}

本方式による気体流れの可視化の特長をあげる.

1）トレーサであるオゾンが気体で，かつ必要な 混入量がきわめて少量 (2Vol\%で十分) であり，ま た混入のために流れの温度が变わることもないので, 流れを乱さない。

2）原才モデルに適用できる.

3）観測空をよごさないので非定常流れの観測が 可能である.

4）トレーサの混合が空間的にも時閒的にも一様 であるから，噴流の巻き込みなどの定量的観測が可能 である。

5 ）写真撮影が可能である.

6 ）流れの全体扣よび局部の観測が可能である.

7 ）トレーサの発生, 混入が容易である.

本力式胥さらに完全なるのにするために，トレーサ であるオゾンをパルス状に混入し（照射紫外光も同様 
にパルス状に変化させれば両者の相関がとれる), 流 れの完全な定量的観測を可能とすることが考兄られる.

これを可能清するなとは, 非常に強力な放電現象 水より瞬間的にオン゙ンを発生する技術の開発，あるい は空気と高濃度のオン゙ンガスを交互に流路に供給し， しかも供給圧を変化させることなく一定に保つ技術の 開発が必要である，後者の技術の開発の可能性をすで 飞確かめ, 現在実験中である。これは，低圧水銀灯が $100 \mathrm{~Hz}$ で点隇すること（電源に $50 \mathrm{~Hz}$ をいた場合） を利用したものであり，2つの側壁付着形素子の呿の 物のにオゾンガスと空気を供給し，これらに $100 \mathrm{~Hz}$ の切換光信号を同期して加光, 括の和のの出力流を合 流させたものを, 観測流路への供給流とする方法であ る.これによりけけ光板上に現われた流れの中のし まの間隔, 形状から流速, 速度分布が得られる. 現在,
肉眼では観測できているが，コントラストの不足のた め満足な写真が得られていない.

気体，液体を問わず，流れの可視法として，本方式 の原理，すなわち非可視光線を吸収する物質をトレー サとして用い, 光ルミネ゙ッセンスを利用して可視化す る方法は，非常に有效なるの之思われる。

最後に, 本実験に協力された東京工業大学学生佐瀬 昭君に感謝致します。㐬たけい光物質と資料をこころ よく提供された大日本塗料株式会社, ならびに Cds 光導電素子と資料を提供さ机た松下電気産業株式会社 に深く感謝致します.

$$
\text { 参考文 献 }
$$

1) B. Kovaliv et E. Briner : Helv. Chim. Acta, 35, 2283 (1952)

2）オゾナイザハンドブック（1960-コロナ社）

\section{第 7 巻 第 2 号 正 誤 表}

（須藤二全・戸恒 明著「 2 相サーボモータの振動トルクの解析」）

\begin{tabular}{|c|c|c|c|c|}
\hline ページ & 欄 & 行 & 䛊 & 正 \\
\hline 107 & 右 & （15）式の一部 & $=2\left(\frac{B_{m}}{2}\right)^{2}(l r)^{2} N_{r}\left[\underline{\underline{\left(\frac{1+K^{2}}{2}\right)}}\right.$ & $=2\left(\frac{B_{m}}{2}\right)^{2}(\operatorname{lr})^{2} N_{r}\left[\left(\frac{1+K}{2}\right)^{2}\right.$ \\
\hline 108 & 左 & (16) 式の一部 & $\underline{\underline{-\left(\frac{1-K^{2}}{2}\right)}}\left(\frac{\left(\frac{R_{r}}{2-S}\right)}{\left.\frac{R_{r}}{2-s}\right)^{2}+\left(\omega L_{r}\right)^{2}}\right.$ & 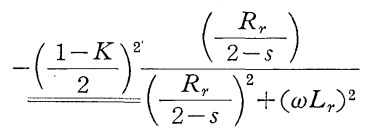 \\
\hline 108 & 右 & (18) 式の一部 & $-\left|\dot{V}_{m b_{1}}\right|^{2} \frac{\left(\frac{r_{2}}{2-s}\right)}{\left(\frac{r^{2}}{2-s}\right)^{2}+\underline{\underline{x_{2}}}}$ & $-\left|\dot{V}_{m b_{1}}\right|^{2} \frac{\left(\frac{r_{2}}{2-s}\right)}{\left(\frac{r_{2}}{2-s}\right)^{2}+\underline{\underline{x_{2}}}}$ \\
\hline 108 & & (20）式分母の一部 & $+\left\{r_{1}\left(x_{2}+x_{m}\right)+\left(x_{1}+x_{m}\right) \underline{\left.\left(\frac{r_{2}}{s}\right)^{2}\right\}}\right.$ & $+\left\{r_{1}\left(x_{2}+x_{m}\right)+\left(x_{1}+x_{m}\right)\left(\frac{r_{2}}{s}\right)\right\}^{2}$ \\
\hline 110 & & (41) 式分母の一部 & $+\left\{r_{1} x_{m}+\left(x_{1}+x_{m}\right) \underline{\underline{\left.\left(\frac{r_{2}}{s_{1}}\right)\right\}}}\right.$ & $+\left\{r_{1} x_{m}+\left(x_{1}+x_{m}\right) \underline{\left.\left(\frac{r_{2}}{s_{1}}\right)\right\}^{2}}\right.$ \\
\hline
\end{tabular}

